\title{
Unpacking the Indirect Effects and Consequences of Environmental Regulation
}

\begin{abstract}
Interantional Journal of Production Economics
Abstract

Environmental regulation and its corresponding measures and control is an important issue but have not been fully investigated. Literature on the unintended consequences of regulation control and measures appears to be sparse. Through a series of exploratory case studies in China, this paper examines the various unintended impacts of ecological civilisation (EC) regulation on firms' operations and their related consequences to performance. Findings showed that there were interrelated themes that underpin the indirect and unintended effects of regulatory control and performance management. This exploratory study can contribute to both theory building and provide important EC policy implications by: (a) enriching the conceptual understanding of the unintended consequences of environmental regulation on firms' behaviours and outcomes, (b) providing policy maker important insights and practical advices for regulating environmental performance.
\end{abstract}

Keywords: Performance Measurement; Environmental Regulation; Indirect Effects; Sustainability; Ecological Civilisation (EC), China.

http://dx.doi.org/10.1016/j.ijpe.2017.01.017

\section{Introduction}

Unintended consequences of performance management is an important issue but have not been fully investigated (Meyer, 2009). The debate on environmental performance management is still limited. Governments tend to use various regulations and measures to enhance environmental performance, both at the local governmental level (achieving public policy goals, such as protecting the environment and public from environmental hazards and minimizing industrial wastes) and at the individual firm levels (achieving sustainable business growth and financial performance goals). Such regulations and measures can have both positive intended and negative unintended effects, depending on firm size, industry, and embedded contexts of the firms (Tan 
and Rae, 2009). However, previous studies have been largely focused on the positive side which can have a short-term effect on environmental performance (Tan et al., 2014; Tseng et al., 2014), but ignoring the potential long-term and indirect effects, which can eventually lead to unintended and negative consequences to performance, both economically and environmentally.

Concerns about sustainable development have grown significantly during the last decade (Brizga et al., 2014; Foo, 2013). In China, sustainable development is guided by a philosophy of 'Ecological Civilisation' (EC). Under the EC philosophical framework, various metrics and indicators were set for regional governments and firms to create more wealth using less energy. However, local government officers or firms may manipulate set metrics to meet their own interests or to cover their failure to meet the various pressures of achieving the set targets (Tan et al., 2014). For example, it was reported that in 2010 there were plethora enforced blackouts in many cities, where hospitals, schools, and traffic lights had their power cut off when local government failed to meet the tough energy and emissions targets set by the central government in 2006 ( $\mathrm{Si}, 2012)$. Clearly, in this incident, the pressure to ensure EC compliance (meeting the set targets, which could be overly broad and complex) had forced the officials to cover the reality by fiddling the data.

Nonetheless, the unintended effect of environmental regulations is not only unique in China, but also in other developed and developing countries. For example, it was only one year after the Fukushima Daiichi nuclear disaster that the Tokyo Electric Power Company (TEPCO) has admitted their failure to meet basic safety requirements (such as risk assessment, collateral damage preparation and evacuation plan development) in fear of eliciting lawsuits or protests against its nuclear plants. There are also a number of examples from the auto-mobile industries recently. Goulder et al (2012) points out that in response to the climate change, 14 states in America took a series of initiatives to limit greenhouse gas emission per mile. The unintended effect of that was the large car manufacturers in the 14 states decided to relocate to other states which have lower emission control. Because the restriction has largely decreased the profit margin of the large-car manufacturer, so rather than devoting to innovation on reducing emission, they chose to move out of the regulated states (Tan et al., 2014). Another recent 
example was related to Volkswagen intentionally programmed their diesel engines to meet US standards during regulatory testing but emit up to 40 times more nitrogen oxide in real-world driving. The above examples suggested that regulated measures not only failed to improve the environmental performance of the automobile industry, but also have unintended consequences to the company long term performance and local economy. In developing countries, one example can be found in the 1989 Hoy No Circula (today it doesn't circulate) scheme introduced by the Mexico City to combat air pollution. The city banned cars for one day per week depending on the last number of their number plate (i.e. cars with last number of 1 and 2 are banned on Monday, then 3 and 4 on Tuesday, and so on). Initially, the scheme achieved good results in bringing down carbon monoxide (CO) pollution levels by $11 \%$. However, the scheme also led to the enlargement of second car market i.e. residents began buying second cars (often old inefficient ones) to get around the ban. The long-term impact of the scheme has been a $13 \%$ rise in CO (Mathiesen, 2014).

Needless to say that EC regulation can cause unforeseen negative consequences in particularly when firms or individuals try to circumvent the regulations to avoid the high costs of compliance or behave opportunistically (Tan et al. 2014). But, what are the scope and extent of these unforeseen consequences that can have impact to economy, society and company performance? The evidence found in existing literature that has focused on the unintended consequences of regulation and its corresponding measures on firms' operations appears to be sparse. In particular, how should firms respond to EC regulation? What performance measurement systems (i.e. metrics) will managers establish to comply with EC regulation? For example, to which extent measurement of performance and the corresponding incentive structure within firms can be compared with what the initial regulation intended. Thus, understanding the potential unforeseen consequences of metrics used by firms to comply with well-intended environmental regulation is vital - especially the unintended negative consequences on local environment and firms' performance.

This paper aims to examine the various unintended impacts of environmental regulation on firms' operations and their related consequences to performance. This paper can contribute to both theory building and provide important policy implications by: (a) enriching the conceptual 
understanding of the unintended consequences of regulation and environmental performance, and (b) providing policy maker important insights and practical advices for regulating environmental performance. The remainder of the paper is structured as follows. The next section reviews the literature on the unintended consequences of environmental regulations and performance measurement systems. Section three outlines the research methodology. The findings are presented in section four, followed by a discussion of their significance and contribution. Finally, limitations and suggestions for future works are articulated.

\section{Theoretical Background}

Interest in performance measurement in sustainable operations has been driven by an increased demand for better environmental and green indicators in firms' operations and economic development (Wu, et al. 2015). There is also emphasis on demonstrating transparency in corporate social responsibility (for firms and governments) especially on environmental management (Huang \& Chen, 2015). Many researches pointed out that tighter environmental regulation and public reporting leads to improvements in environmental management, and reported data provides information on areas of underperformance, leading to a stimulus (regulations) for improvement from the policy makers (Bricknell, 2010; Gilliland et al.,2002; Goulder et al., 2012; Powell, 2011; Tan and Rae, 2009). However, the assumption that regulations will result in improvements in environmental management rests on the assumption that the outcome being measured is amenable to compliance or improvement.

How performance measures are used does varies with firms (Meyer, 2009). Unfortunately, most of the performance measurement (PM) literature focuses on the corporatelevel measures that monitor results rather than on measures that motivate appropriate behaviour (Weidinger and Platts, 2012; Waggoner et al. 1999). Performance measures at the corporate level tend to be aggregated (while appropriate to indicate overall firm performance), may not be suited to motivate appropriate employees' behaviour to comply rigid environmental regulation measures. Thus, regulators must be conscious of the extent to which environmental metrics can be manipulated or gamed by firms, or the extent to which the metric can encourage undesired 
behaviours. As such, regulation without robust metrics can affect a firm's strategic direction and operations in different ways for different firms as well as triggering many unintended negative consequences to the environment.

In the organizational theory literature, unintended consequences are the result of environmental uncertainty and the bounded rationality of organizational actors (Selznick, 1948). Predicting a manager's action in an uncertain and complex world is not easy. Thus, some of the unintended consequences could be unstated, but not unintended (Osborn and Daniel, 1988). Tan and Rae (2009) argue that the impact can be dependent on firm size, industry, and the environmental and social contexts the firm located in. They further argued that the short-term implications of regulation and PM on the firm can be very different when comparing with the long term implications. For instance, regulation and performance measurement increases costs and reduces efficiency for all firms, but the impact will be greater for the smaller firm. In longterm, most of the firms may attempt to find ways to reduce the costs and increase efficiency, though some may choose to minimize the compliance to regulation, whilst others through process improvement and innovation, but this will be achieved a lot quicker by the bigger firm who has more resources (Tan et al. 2014).

Clearly, the outcomes of performance measures can have an interlocking impact on the effectiveness of the regulation. Nonetheless, in the literature there are only a few articles that mentioned unintended consequences of PM and regulation. These authors (Adcroft and Willis, 2005; Brigham and Fitzgerald, 2001; Humphreys and Francis, 2002; Shaffer, 1995; Tan and Rae, 2009) highlight that the relationship of regulation and PM is an area relatively unexplored. There are strong links exist between regulation and PM at firm level, in which regulation can have significant impact on the performance of the firm and the types of performance measures it uses. Tan et al. (2014) identified that regulation impacts on the firm at different levels: from the strategic level to the individual employee level, which in turn affect the performance measurement systems used by the firm.

\section{Research Methodology}

The study of the unintended consequences of regulation and performance measures has relatively little theoretical background (Tan and Rae, 2009; Tan et al. 2014). Thus, in order to 
gain more insights into the issue, a series of empirical and archival case studies were carried out. The aim of the case study was to understand the scope, extent, and causes of unforeseen consequences of EC regulations. More specifically, the objective was to understand how best to achieve EC compliance and mitigate unforeseen consequences. ). Figure 1 provides a graphical representation of the key steps in the research process.

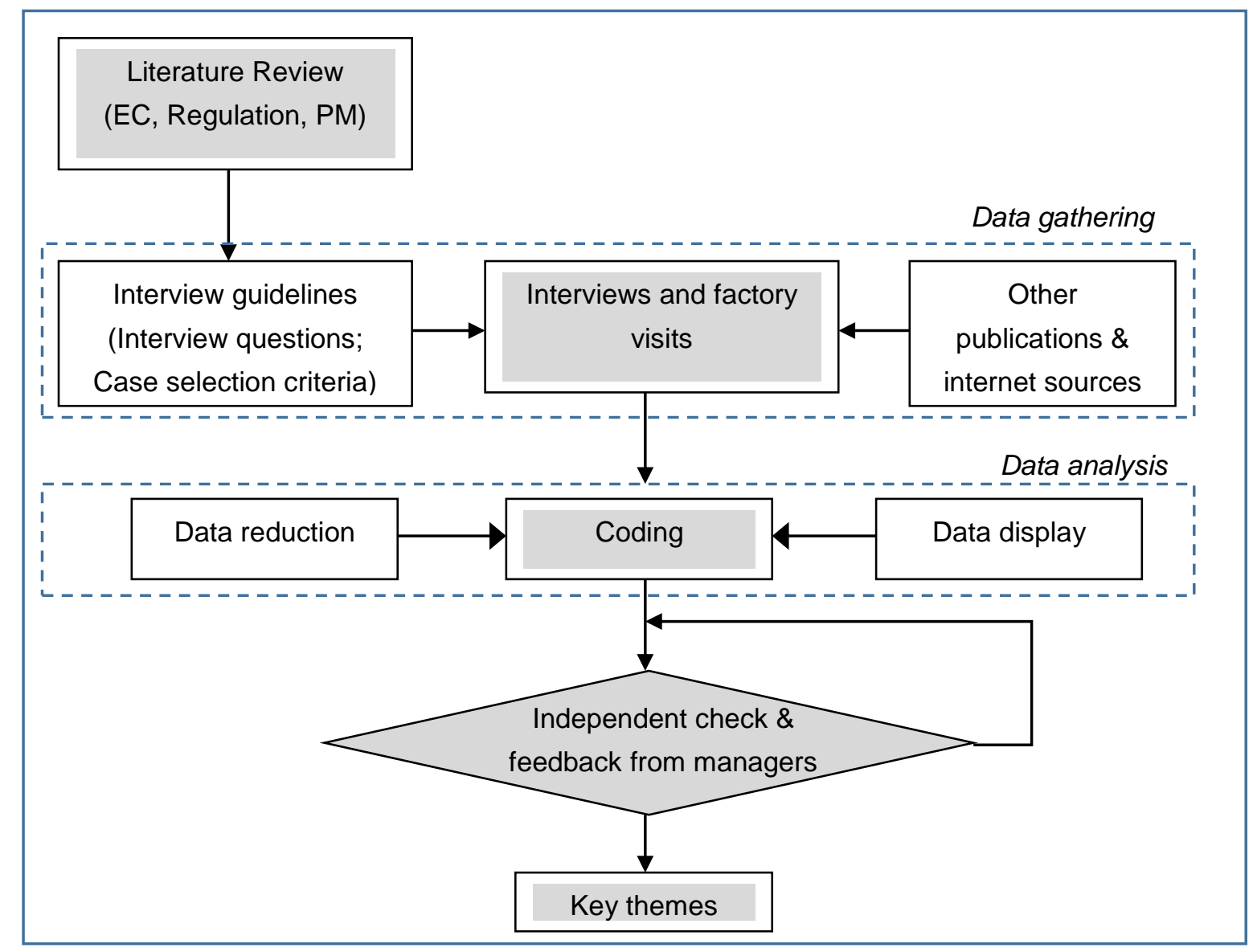

Figure 1: Key Steps in the Research Process

\subsection{Case selection}

A case study with six Chinese firms was conducted in this research. In order to enrich the data for building theory via case studies, researchers normally select cases using replication rather than sampling logic (Done, Voss \& Rytter, 2011; Pagell \& Wu, 2009). Thus, it is vital to select cases that provide the best opportunities to learn and extend theory. Two of the authors in this 
paper have a good contact within these firms, and thus able to get permission to gain access to individuals who are best informed about the data being researched. The willingness to cooperate for detailed discussion for such a sensitive research topic is crucial for generating in-depth data for the study.

Justifications for the case selection are: a) these six firms are willing to share and discuss openly their experiences in dealing with EC regulatory control; b) the cases include some of the dynamic experiences of Chinese firms in managing growth and meeting environmental regulation challenges in local and global markets in recent years; and c) the cases cut across various geographical locations in China. The variety in the cases was a deliberate research design strategy chosen to increase the external validity of the study's findings, and to assure that the findings were generalizable and not specific to any one type business or market (Yin, 1984). Synopses of the six firms are provided in Table 1.

Table 1: Case Background

\begin{tabular}{|c|c|c|c|c|c|}
\hline Cases & $\begin{array}{l}\text { Primary business and } \\
\text { activities }\end{array}$ & Headquarter & Interviewee position & $\begin{array}{l}\text { Interview } \\
\text { duration }\end{array}$ & $\begin{array}{l}\text { Annual } \\
\text { turnover }\end{array}$ \\
\hline $\begin{array}{l}\text { A- Housing } \\
\text { developer }\end{array}$ & $\begin{array}{l}\text { Design and build housing } \\
\text { estates in China, Africa, } \\
\text { and Asia. }\end{array}$ & Beijing, China & Project manager (mgr) & 65 mins & $\begin{array}{l}\text { >2billions } \\
\text { Yuan }\end{array}$ \\
\hline $\begin{array}{l}\text { B - Machinery } \\
\text { manufacturer }\end{array}$ & $\begin{array}{l}\text { Testing, manufacturing, } \\
\text { and design of advanced } \\
\text { turning machines. }\end{array}$ & Beijing, China & $\begin{array}{l}\text { Sales mgr } \\
\text { Operations mgr }\end{array}$ & $\begin{array}{l}90 \text { mins } \\
45 \text { mins }\end{array}$ & $>100 \mathrm{~m}$ Yuan \\
\hline $\begin{array}{l}\mathrm{C}-\text { Medical } \\
\text { equipment } \\
\text { manufacturer }\end{array}$ & $\begin{array}{l}\text { Testing, design, } \\
\text { manufacturing, and after } \\
\text { sale services. Mainly to } \\
\text { hospital and private clinics. }\end{array}$ & $\begin{array}{l}\text { Shanghai, } \\
\text { China }\end{array}$ & $\begin{array}{l}\text { CSR mgr } \\
\text { Operations mgr }\end{array}$ & $\begin{array}{l}50 \text { mins } \\
60 \text { mins }\end{array}$ & $>500 \mathrm{~m}$ Yuan \\
\hline $\begin{array}{l}\text { D - Display } \\
\text { manufacturer }\end{array}$ & $\begin{array}{l}\text { Design and manufacture } \\
\text { display products }\end{array}$ & Guangzhou, China & $\begin{array}{l}\text { CEO, } \\
\text { Operations mgr } \\
\text { Sales mgr }\end{array}$ & $\begin{array}{l}70 \text { mins } \\
45 \text { mins } \\
65 \text { mins }\end{array}$ & $>100 \mathrm{~m}$ Yuan \\
\hline $\begin{array}{l}\text { E-Coating } \\
\text { manufacturer }\end{array}$ & $\begin{array}{l}\text { Research, } \\
\text { manufacturing of new } \\
\text { materials for machinery } \\
\text { coating }\end{array}$ & $\begin{array}{l}\text { West Shanghai, } \\
\text { China }\end{array}$ & $\begin{array}{l}\text { CEO, } \\
\text { Operations mgr } \\
\text { CSR mgr } \\
\text { R\&D mgr }\end{array}$ & $\begin{array}{l}45 \text { mins } \\
45 \text { mins } \\
80 \text { mins } \\
60 \text { mins }\end{array}$ & $>200 \mathrm{~m}$ Yuan \\
\hline $\begin{array}{l}\text { F- Electronic } \\
\text { manufacturer }\end{array}$ & $\begin{array}{l}\text { Testing, manufacturing, } \\
\text { and design of advanced } \\
\text { protecting products }\end{array}$ & Shenzhen, China & $\begin{array}{l}\text { R\& D mgr } \\
\text { Project mgr }\end{array}$ & $\begin{array}{l}90 \text { mins } \\
75 \text { mins }\end{array}$ & $>100 \mathrm{~m}$ Yuan \\
\hline
\end{tabular}

\subsection{Data Collection}


For each case, we collected data from different sources, including repeated field visits and interviews of managers from different organizational levels and functions: including senior management (i.e. CEO, Operations Manager, R\&D Manager and Corporate Social Responsibility (CSR) Manager), and Project Managers. Using multiple interviewees brought a richer portrait of each case (Yin, 1984), and also to mitigate bias when come to historical data interpretation (recollection).

The interviews were conducted between 2013 and 2014. All interviews were conducted via face-to-face interviews in companies either in the managers' offices or meeting rooms and lasted about 45 to 90 minutes. Informal interviews also took place with other front line staff when the interviewers were conducting field observations. Field notes were taken throughout the visits. Various vignettes on unintended actions that managers commonly make in motivating and measuring their organizations with EC measures were collected, including multiple sources of data from published documents in the company website and independent publications. We also check out a relevant NGO website i.e. Green Choice Alliance (IPE, 2015) for relevant cases, news, and reports.

All the formal interviews were agreed to be tape-recorded and then transcribed into hard copy scripts using word processing programme. In order to avoid researcher bias in data collection and analysis, visits to case study sites were conducted in pairs; this allowed the case to be viewed from different perspectives. Due to the fact that both interviewees and interviewers are native Mandarin Chinese speakers, it will be convenient for the interviews to be conducted by their first language. Hand-written notes were also taken as a backup in the event of equipment 
failure. Each transcript can then be reviewed to compare the observation between the two interviewers. In addition, we also shown the final draft of transcripts to the interviewees to confirm that the contents truly reflected the interviewees' original meaning.

The aim of the interviews was to understand the scope, extent, causes, environmental and organizational factors (both internal and external) that underlying the studied phenomenon (a brief summary of the interview questions is shown in Table 2). Hence, the data are drawn from multiple levels and various perspectives. The extent of the fieldwork, the number of interviews, and the quality of the data provides rich data and important insights for the present study. Through triangulation with multiple sources of data collection, the research validity can be strengthened.

Table 2: A brief summary of the interview questions

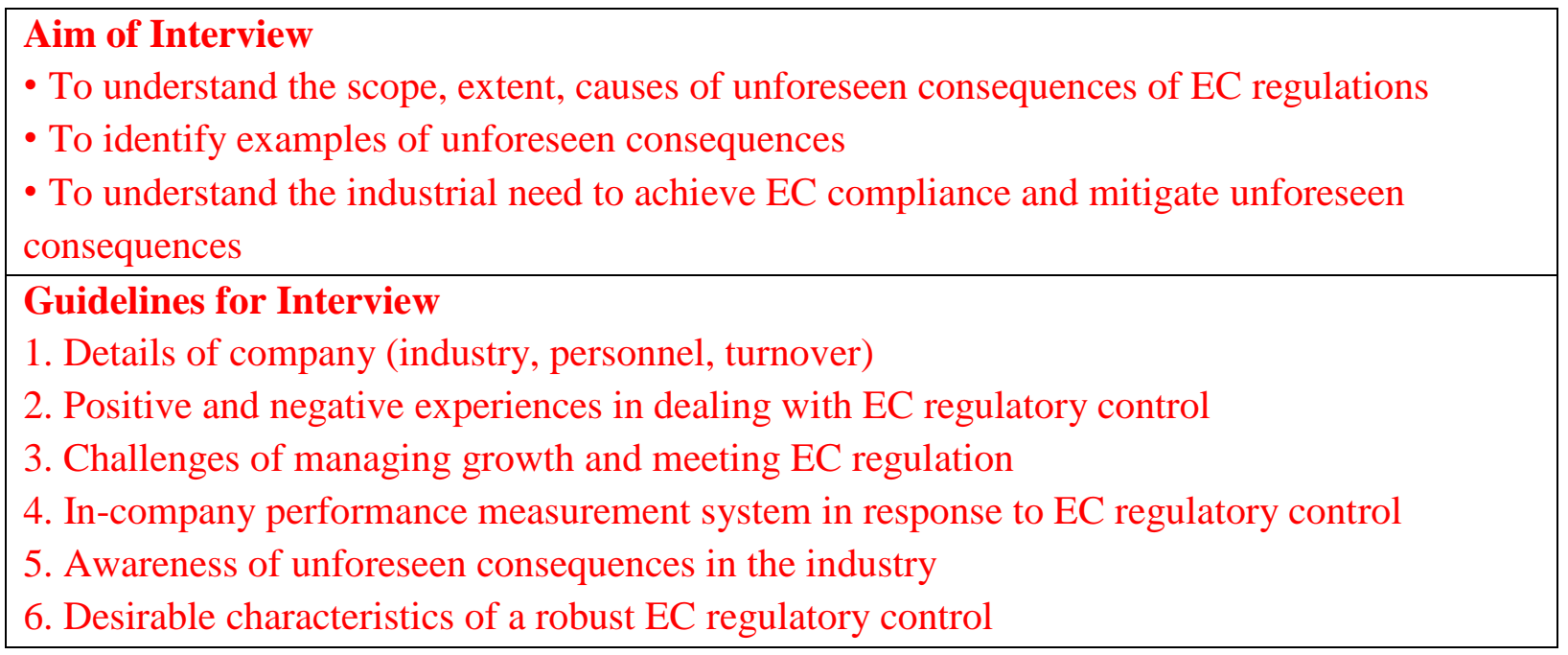

\subsection{Data Analysis}

The purpose of data analysis is to construct a theoretical framework as the story unfolded and to enrich the newly identified concepts for further theoretical articulation. The exploratory approach is recommended for this study context because it can help to examine the phenomenon 
within various organizational contexts, define the boundaries, and triangulate data from different sources.

The collected data were analysed through a systematic approach of three phrases: data reduction, coding, and data display (Miles and Huberman, 1994; Locke, 2001). The transcribed codes were categorized in terms of interview number, company name and question number. After several iterations, a pattern of well-defined codes (e.g. common themes and categories) was generated and identified. By investigating the statement of relationship between various measures, regulation control, and performance outcomes, we are able to explain the main themes with their conceptual properties. The final stage was to generate the relationship among the themes and categories and further explain the unforeseen consequences of environmental measures and performance. In order to ensure the accuracy of the codings, the author feedback the research data to the interviewed managers. An example of coding is shown in Table 3. In addition, the codings were also double-checked by an independent reviewer who is blind to the purpose of the research. The reviewer was given some representative codings and statements from the data of each category, and instructed to code them separately. The findings were discussed with this reviewer to confirm the reliability of codings and meanings of the data. The overall agreement of the coding samples is over $85 \%$. This analytical approach helped to construct theory and ensure the reliability and validity of the findings (Eisenhardt 1989).

Table 3. Examples of coding

\begin{tabular}{|l|l|}
\hline Examples (Quotes) & Themes coded \\
\hline $\begin{array}{l}\text { Some sort of social behaviour control maybe useful given the } \\
\text { context of Chinese social structure - Case F }\end{array}$ & Regulatory control \\
$\begin{array}{l}\text { An effective approach should be flexible enough to promote } \\
\text { self-regulation and voluntary participation - Case C }\end{array}$ & \\
\hline
\end{tabular}


A mix approach to environmental regulation (punishment, transparency and flexibility) - Case C

The lack of clearly defined measures can cause uncertainty among firms as to what could be considered deceptive or perverse - Case A

Many firms fall short of full compliance in EC regulations at some points, but they believe fines due to violation of $\mathrm{EC}$ regulations were just a small cost of doing business - Case B

Measures to decrease gaming are necessary to prevent perverse outcomes. EC goals should be specific, ambitious, and measurable against an established baseline, such as carbon emissions - Case F

\section{Findings and Discussion}

In our analysis, three main themes emerged from the case studies were: regulatory control; indirect effects, and dysfunctional of performance measurement. In the following sections, each theme will be explored in more in-depth.

\subsection{Regulatory Control}

Participants in all six cases pointed out that regulatory control is one of the main issues need further improving. Currently, the EC environmental regulatory system that involving a complex set of laws and guidelines seems difficult for them to follow. Moreover, the enforcement power also can be confusing as it usually involves the central government and their various regional and local affiliates. The aim of the regulatory system is to protect the environment and public from environmental hazards and/or industrial wastes. However, participants in Cases $\mathrm{C}$ and $\mathrm{E}$ point out that when regulated firms failed to conform to the EC rules prescribed by law and administered by the controlling agency, the results can be dreadful. For example, firms that failed to conform will be asked to cease operations and pay massive fines. A manager in Case A argued that it is important to examine the regulatory control mechanisms at the field level and how regulated firms respond to these controls.

The concerns raised by the participants in the case studies echo the findings in the literature. Gililand and Manning (2002) point out that conformance, which is difficult to achieve 
in many inter-organizational settings, is particularly problematic in a regulatory context because of the ideological differences that exist between agencies and firms. These differences in ideology pertain to issues such as the role government regulators should play in meeting public policy goals and the high perceived cost of compliance to mandated standards (Wang, et al. 2011). One manager in Case B pointed out that many firms view EC regulatory legislation as overly broad, complex and conformance is tedious and cumbersome. In light of that, many firms will try to circumvent the regulations to avoid the high costs of compliance (Pautz, 2011).

In literature, the dominant views on regulation control are tit-for-tat enforcement strategy (TFT) (Scholz, 1984) and enforcement pyramid (Braithwaite, 1989). The TFT and the enforcement pyramid are both based on the premise that best-practice regulation must incorporate a mix of punishment and persuasion (Bricknell, 2010). Managers in Case E argue some of the current penalties are too steep with the threat of increasing sanctions if non-compliance continues. However, managers in the case studies differ on how intricate or complex the punishment needs to be. Managers in Cases D and F pointed out that to be really effective the penalty should be as steep as possible, for example, incapacitation in the form of licence suspension and (or) sentencing senior managers to jail should be included.

Thus, given the context of Chinese social structure, social control theory (Ellickson, 1987; Gibbs, 1989) maybe useful in explaining issues in which the policies of environmental protection intersect with the interests of firms. Table 4 shows the three elements of EC regulatory control system (adapted from Ellickson (1987), Gililand and Manning (2002): a) regulatory controller; b) informal control; and c) formal control. Thus, to ensure EC regulation compliance, all three elements of control system need to be explored further. The manager in Case A pointed out that by considering compliance and opportunism, it is only possible to investigate both intended and unintended effects of EC regulation i.e. the extent to which firms willingly comply or behave opportunistically to avoid discovery.

Table 4. Environmental Regulatory Control System 


\begin{tabular}{|l|l|}
\hline \multicolumn{1}{|c|}{ Elements } & \multicolumn{1}{c|}{ Description } \\
\hline $\begin{array}{l}\text { Regulatory } \\
\text { controller }\end{array}$ & $\begin{array}{l}\text { A regulatory agency with legally granted authority to administer } \\
\text { the rules of control and force compliance on firms within its } \\
\text { jurisdiction. }\end{array}$ \\
\hline Informal control & $\begin{array}{l}\text { Using interpersonal norms, social instruction, religions practice, } \\
\text { and flexibility in consideration of the situation to influence } \\
\text { firms to adhere to the environmental rules. }\end{array}$ \\
\hline Formal control & $\begin{array}{l}\text { A strict interpretation of EC guidelines. Any violations will not } \\
\text { be tolerated i.e. offences will be punished under the } \\
\text { environmental rules. }\end{array}$ \\
\hline
\end{tabular}

Managers in Cases A and C pointed that there should not be a one size fits all approach for regulatory control. An effective approach should tailor to local requirements and be flexible enough to promote self-regulation and voluntary participation. The manager in Case A shared his frustration with the current traditional command and control approach to regulation. He argued that there should be more voluntary agreements, education and information schemes, as well as market imposed pressure to guide EC enforcement. In short, the participants prefer a mix approach to environmental regulation that is grounded in punishment, transparency and flexibility (Bricknell, 2010).

\subsection{Indirect or Unintended or Unforeseen Consequences}

Oxford English dictionary defines unintended consequences as 'an activity that has produced a consequence that was not planned with any intent or purpose'. Thus, many participants in the case study argued that it is vital to understand the meaning and also the causes of unintended consequences. The good intention of EC regulations could result in a positive or negative effect on the firm and its environment. Thus, policy makers need to fully understand or anticipate the causes of unintended consequences if they were to develop effective EC regulations. Merton (1936) pointed out five possible causes of unanticipated consequences as:

- Ignorance - Incapable to anticipate everything which lead to incomplete analysis

- Error- Incorrect analysis of the problem

- Immediate interest - Influence by current priority that overrides long-term interests

- Basic values - Prohibit certain actions even if the long-term results might be unfavorable

- Self-defeating prophecy - Anticipate solutions before the problem occurs due to fear of some consequences or uncertainties. 
One of the managers in Case B shared his recent experience. In the drive to meet the carbon footprint measure, he found that inventory at various warehouses had increased in two folds and machine utilisation had suffered in general. This is because a truck will not deliver goods unless it is on full load (in order to reduce carbon footprint). Hence, managers will put on different goods to fill up the truck or delay the delivery (resulting in machine stoppage in plants that waiting for the parts). He further pointed out that good performance on certain chosen measures is not good enough, and likely to produce unintended consequences, if unchecked. EC measures should align with a firm's corporate strategy and with performance that safeguard a firm's success, such as customer satisfaction, sustainable operations, and others. Clearly, it is vital for policy makers to understand the causes of unintended consequences when setting EC measures.

In the literature, many scholars point out that deliberate change to a system may result in unintended consequences ( $\mathrm{Lu}$ et al. 2007; Wang et al. 2011). More than often, these effects are unanticipated and beyond the control of the managers who introduced them. A list of unanticipated effects in literature is shown in Table 5.

Table 5: Various Sources of Unanticipated Effects Identified in Literature

\begin{tabular}{|l|l|}
\hline \multicolumn{1}{|c|}{ Effects } & \multicolumn{1}{c|}{ Descriptions } \\
\hline The placebo effect & $\begin{array}{l}\text { Widely reported in medicine. A doctor's belief in the treatment } \\
\text { casts large positive effects on the patient. The result is a powerful } \\
\text { remedy, where the intervention in fact has no material effect, but } \\
\text { the belief by the participant does (Hart, 1999). }\end{array}$ \\
\hline $\begin{array}{l}\text { The Hawthome } \\
\text { effect }\end{array}$ & $\begin{array}{l}\text { The effect of simply being studied. The effect did not depend on } \\
\text { the particular expectation of the researchers, but that being studied } \\
\text { caused the participants to improve their performance } \\
\text { (Roethlisberger and Dickson, 1939). }\end{array}$ \\
\hline The halo effect & $\begin{array}{l}\text { The effect of uncontrolled novelty i.e. participants perform } \\
\text { differently (to be more alert or otherwise perform differently) } \\
\text { because of the novelty of the treatment (Thorndike, 1920). }\end{array}$ \\
\hline $\begin{array}{l}\text { The Pygmalion } \\
\text { effect }\end{array}$ & $\begin{array}{l}\text { A self-fulfilling prophecy. Teachers' expectations of pupils can } \\
\text { strongly affect the amount of development they show (Rosenthal } \\
\text { and Jacobson, 1968). }\end{array}$ \\
\hline $\begin{array}{l}\text { The John Henry } \\
\text { effect }\end{array}$ & $\begin{array}{l}\text { The opposite of the Hawthome effect: it is when a supposedly } \\
\text { control group, that gets no intervention, compares themselves to } \\
\text { the experimental group and through extra effort gets the same } \\
\text { effects or results (Saretsky, 1972). }\end{array}$ \\
\hline
\end{tabular}


One of the participants point out that the negative consequences of unclear EC regulations are many. For example, the lack of clearly defined measures can cause uncertainty among firms as to what could be considered deceptive or perverse. Risk-averse firms may therefore choose to avoid certain products altogether, even when their manufacturing operations are environmentally sound. One manager in Case D argues that the lack of consensus and clear definition in the EC regulations may create more harm than good. For example, it may impede firms' competitive advantage in the market place if environmentally sound products were regarded otherwise. Nonetheless, he argues one positive unintended consequence of EC is instillation of strong interests in environmentalism within a firm. Implementing EC often results in the creation of an environmental affairs department (for large firms, in general) and the establishment of employee environmental education programs (Feinstein, 2013). Thus, clear and careful EC regulations will bring direct positive consequences with little unforeseen negative effects.

\subsection{Dysfunctional Effects of Environmental Performance Measures}

During the case studies, a few concerns were raised by the managers on the negative unintended effects of regulations on environmental management measures and environmental performance. One manager highlighted that some of the EC measures are not specific enough, thus providing an opportunity for some firms to 'play game' with the measures. Most participants believe that robust measures fit for accountability purposes are required to reduce unintended negative consequences. This view is echoed in Ridgway (1956) seminal article that pointed out that firms experience dysfunctional consequences of performance measurements due to indiscriminate use or from insufficient knowledge of the full effects and consequences. One participant pointed out that "many firms fall short of full compliance in EC regulations at some points, but they believe fines due to violation of EC regulations were just a small cost of doing business". One of the managers pointed that many firms believe they could use poor (broad and not rigorous) environmental management measures set by the central government to skirt EC laws.

One participant in Case E, whose plant develops and produces coating materials, related her dissatisfaction with the performance measurement system at her firm. The measures in her plant changes frequently (quarterly or so). One quarter the performance measurement emphasized was flexibility (i.e. ability to change volume and product range to suit last minute 
customer demands). The performance measure emphasized that follows was the machine efficiency. She argues that it is difficult to juggle two in-compatible measures at the same time without long term changes in operations practices. The continual change in direction caused by the "shifting goal post" is frustrating. Moreover, it is hard to maintain a consistent focus and to remain motivated, she reckoned.

Similar views were pointed out one participant in Case B pointed out the ever-changing measures to reflect the "hot" item of the month is a form of punishment. Punishment does nothing to increase the likelihood of good performance and will only eliminate the poor performance temporarily (Solomon, 1964). Many scholars (Blossom et al, 1999; Meyer, 2009; Tan and Rae, 2009) reported dysfunctional consequences of performance measurement systems. Through information gathered from the case study and the archival studies, Table 6 shows a list of possible poor EC measures that led to unintended consequences.

Table 6: Various Sources of Poor Environmental Management Measures 


\begin{tabular}{|c|c|c|}
\hline $\begin{array}{c}\text { Categories of } \\
\text { Poor Measures }\end{array}$ & $\begin{array}{l}\text { Dysfunctional } \\
\text { consequences }\end{array}$ & Examples \\
\hline Myopia view & $\begin{array}{l}\text { Concentrate on } \\
\text { immediate or short term } \\
\text { issues at the expense of } \\
\text { important long-term } \\
\text { considerations }\end{array}$ & $\begin{array}{l}\text { Firms pumped industrial waste water } \\
\text { deep into the underground in order to } \\
\text { reduce the cost of waste water treatmen } \\
\text { (Kaiman, 2013). }\end{array}$ \\
\hline $\begin{array}{l}\text { Measurement } \\
\text { fixation }\end{array}$ & $\begin{array}{l}\text { Too focus on meeting } \\
\text { the targets at the } \\
\text { expense of wider EC } \\
\text { laws }\end{array}$ & $\begin{array}{l}\text { The introduction of "odd and even" } \\
\text { licence number restriction to limit gas } \\
\text { emission in Beijing had led to the } \\
\text { enlargement of second car market i.e. a } \\
\text { household will buy second cars (have } \\
\text { both odd and even licence number } \\
\text { plates) for emergency use (Mathiesen, } \\
\text { 2014). }\end{array}$ \\
\hline Misinterpretation & $\begin{array}{l}\text { Employees fiddle the } \\
\text { data (creative } \\
\text { accounting or fraud) to } \\
\text { meet the EC measures. }\end{array}$ & $\begin{array}{l}\text { In } 2010 \text {, plethora enforced blackouts in } \\
\text { many southern cities in China where } \\
\text { hospitals, schools, and traffic lights had } \\
\text { their power cut off when local } \\
\text { government failed to meet the tough } \\
\text { energy and emissions targets set by the } \\
\text { central government ( } \mathrm{Si}, 2012) \text {. }\end{array}$ \\
\hline Tunnel view & $\begin{array}{l}\text { Mainly focusing on the } \\
\text { set measures and } \\
\text { ignoring (or neglect) } \\
\text { other important but } \\
\text { unmeasured aspects of } \\
\text { EC regulations. }\end{array}$ & $\begin{array}{l}\text { One state-owned mining firm that } \\
\text { provides } 70 \% \text { of local revenues was } \\
\text { only lightly reprimanded by officers for } \\
\text { its failure to observe environmental } \\
\text { protection regulations. Subsequently, } \\
\text { the firm caused two major pollution } \\
\text { incidents in } 2010 \text { (Hilton, 2014). }\end{array}$ \\
\hline
\end{tabular}

During the case studies, managers also provided many examples of poor measures and the dysfunctional consequences. Managers in Case $\mathrm{F}$ argue that measures to decrease gaming are necessary to prevent perverse outcomes. EC goals should be specific, ambitious, and measurable against an established baseline, such as carbon emissions. Firm F has a long-term orientation (more than four years) that is cascaded down into business strategy. In other words, the measures should be unmistaken by all employees. One of the good practices was illustrated by Case D. To meet the EC carbon emissions measure, the initial measure setup in the factories was "reduce packaging". However, the measure is vague and doesn't say the target (how much to reduce), the formula for its calculation, how often to collect the data, when to achieve the target, or compared with what benchmark. As a result of this, employees fiddle the measure in order to achieve the set target (avoid punishment). One of the plant managers in Case D eventually realised the mistake and develop a robust and more specific measure i.e. "reduce 5 million tons of packaging 
by 2012 in the Make \& Pack department". With a robust measure, it is easier for everyone in the Make \& Pack department to gear toward the goal together with clear objective.

Clearly, in terms of EC regulations, engagement with firms is an essential part of producing meaningful performance measures. One of the participants stated that a collaborative relationship between policy makers and firms (based on mutual trust) is required for long-term progress. The manager in Case A highlighted that firms should be involved in the formulation of EC measure to ensure it is developed according to its intended use. A feasible and effective level of specificity in the EC measures must be laid down (Sueyoshi \& Goto, 2012). Moreover, regulators should not merely have a say in nature of the choice of outcome measure, but also in how it is best communicated to firms and the wider public.

\section{Implication of the Research}

Moving forward, regulators should take into consideration the advantages and shortcomings of the various unintended consequences highlighted in section 4 when setting EC measures. The aim is to minimize confusion and susceptibility to opportunist behaviour. Figure 2 illustrates how deliberate EC measures could be resulted in either positive or negative consequences. Often, unclear or unrealistic EC goals may trigger or encourage firms to game or bend ethical rules. For example, in Case D, one of the managers highlighted that when CEO tells managers to do whatever it takes to achieve the set EC measures, it will invite questionable responses (as managers face difficulties in complying but dare not raise the issue). Thus, EC or managers may routinely encourage or delegate unethical behaviours to other, and not always consciously (Bazerman and Tenbrunsel, 2011). EC regulators and firms have a history of complicated interactions regarding environmental regulation (Feinstein, 2013). Firms tend to perceive EC regulation as costly and imposing constraints on firms' freedom to manage operations. Many managers criticise command and control approach to EC being not flexible (for firms to meet environmental objectives in different forms). Moreover, there is a lack of incentives to encourage firms to go extra miles to improve environmental performance beyond compliance. As illustrated 
in Figure 2, the unintended effects of EC regulations are that firms unable to comply may fiddle with the measures. The results will be negative unforeseen consequences from well-planned policies.

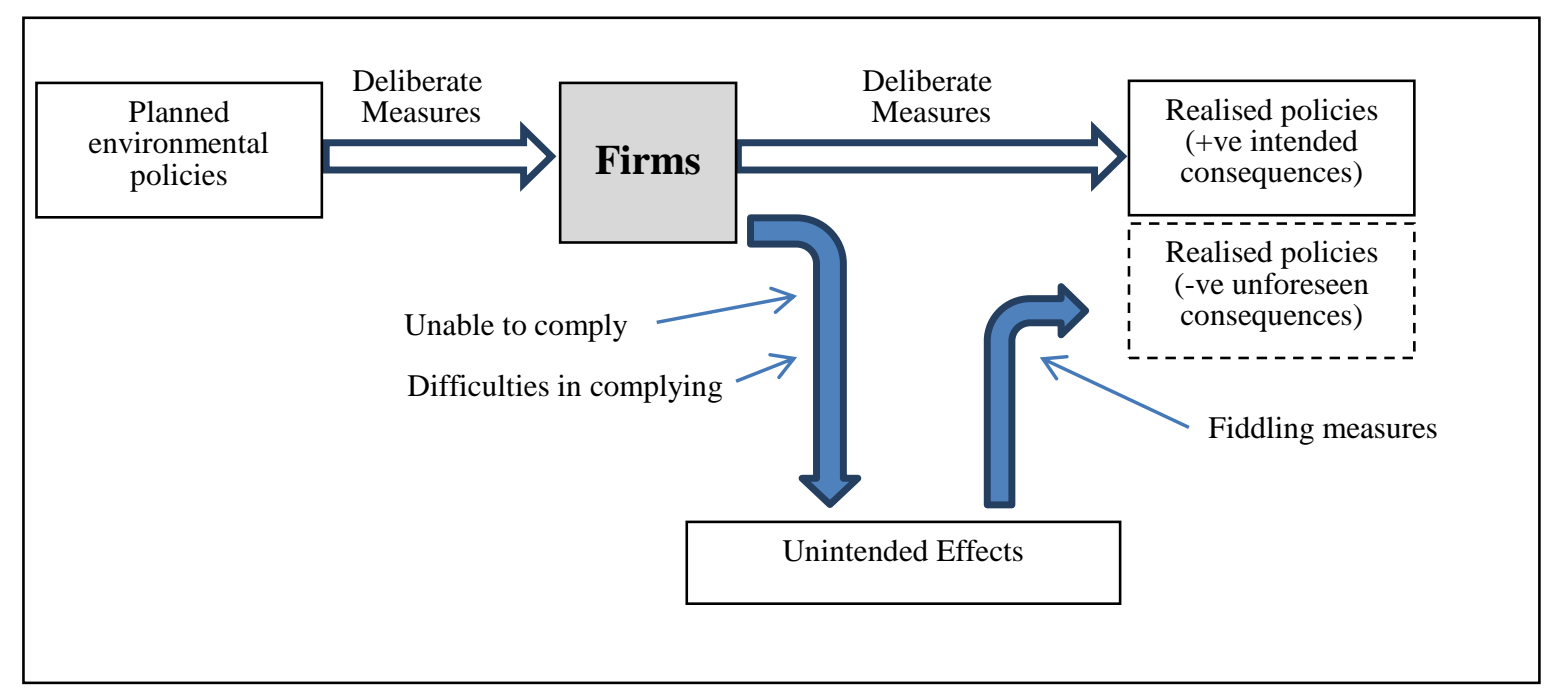

Figure 2: Unforeseen consequences

\section{Conclusion}

This research provides a significant contribution to knowledge to EC, regulatory control, and PM related research. A good understanding of the linkages between regulatory control and PM will assist policy makers by providing knowledge about the potential unintended consequences of their policies. Thus, policy makers could take this research finding into consideration when setting policy frameworks (i.e. by minimizing the negative effects and be able to take advantage of the positive consequences). The three main themes identified in this research provide valuables lessons to EC regulation policy settings and research. Table 7 summarizes the theoretical and practical implications of the research findings. It also highlights the similarities of comments across the cases.

- $\quad$ Regulatory control - To stay competitive in today's global market, reducing operating costs is the top priority of many firms. However, in order to reduce the cost associated with EC compliance, some opportunist firms will deliberately try to circumvent the regulations. In this study, our research findings show that a poor understanding of the indirect effects of regulatory control may lead to more harm than good. For example, existing formal control may increase the level of opportunist conduct. From the case studies, we found that social control theory (Ellickson, 1987) could be used to better understand or manage how firms skirting EC laws. An 
effective approach should tailor to local requirements and be flexible enough to promote selfregulation and voluntary participation. By considering compliance and opportunism, it is only possible to investigate both intended and unintended effects of EC regulation i.e. the extent to which firms are willing to comply or to behave opportunistically for avoiding discovery. There should be more voluntary agreements, education and information schemes, as well as market imposed pressure to guide EC enforcement; rather than just the traditional command and control approach.

- Indirect effects - We identified various unanticipated effects reported in literature that could enable policy makers to understand the nature of unintended consequences. This research highlights that any changes to a system can have unintended consequences i.e. strong ripple effects beyond the control of policy makers who introduced them. The result is something which could have a positive or negative effect on the firm and its environment. Lack of clearly defined measures can cause uncertainty among firms as to what could be considered deceptive or opportunist conduct. When setting measures, regulators and managers should be clear on whose behaviour they are trying to influence and consider their potential responses. Regular reviews are required to adjust the measures to suit the intended purposes. Thus, future research into unintended consequences of EC regulations should pay attention to the various sources of unintended consequences identified in this research.

- Dysfunctional of performance measurement - In this research, we highlighted various categories of dysfunctional consequences of performance measurement systems. Thus, only measures with little room of inducing unintended adverse consequences should be used for accountability purposes. Moreover, regulators should not merely have a say in nature of the choice of outcome measure, but also in how it is best communicated to firms and the wider public. In the research, we found that most firms would benefit from bringing more discipline to their EC initiatives by applying basic performance measurement principles: set specific and robust measures, create accountability for performance, eliminate the tendency to instil fear, and communicate the results to better motivate the workers. Thus, further research in this area is 


\section{necessary for a better understanding of how behaviour may be oriented toward better}

accomplishment of EC regulations.

Table 7. Theoretical and Practical Implications of Research Findings

\begin{tabular}{|c|c|c|c|}
\hline Main Theme & Phenomenon & Theoretical Implications & Practical Implications \\
\hline $\begin{array}{l}\text { Regulatory Control } \\
\text { EC regulatory system too } \\
\text { complex (A,B,C,D,E,F) } \\
\text { A mix approach } \\
\text { (punishment, transparency } \\
\text { \& flexibility) needed to EC } \\
\text { regulation (B,C,D,E,F) } \\
\text { Harsh punishment if } \\
\text { regulated firms failed to } \\
\text { conform to the EC rules.(C, } \\
\text { D,E) } \\
\text { To what extent firms } \\
\text { willingly comply or behave } \\
\text { opportunistically to avoid } \\
\text { discovery (A, F) } \\
\text { An effective approach } \\
\text { should be flexible enough } \\
\text { to promote self-regulation } \\
\text { and voluntary participation } \\
\text { (A, C) }\end{array}$ & $\begin{array}{l}\text { Opportunist firms } \\
\text { will deliberately } \\
\text { try to circumvent } \\
\text { the regulations. }\end{array}$ & $\begin{array}{l}\text { Social control theory } \\
\text { (Ellickson1987): To } \\
\text { promote self-regulation } \\
\text { and voluntary } \\
\text { participation. }\end{array}$ & $\begin{array}{l}\text {-Promote voluntary } \\
\text { agreements, education, } \\
\text { information scheme, and } \\
\text { market pressure for } \\
\text { environmental best practices. } \\
\text {-Don't rely solely on } \\
\text { traditional command and } \\
\text { control approaches. }\end{array}$ \\
\hline $\begin{array}{l}\text { Indirect Effects of regulatory } \\
\text { control to firms } \\
\text { The lack of clearly defined } \\
\text { measures can cause } \\
\text { uncertainty among firms as } \\
\text { to what could be } \\
\text { considered deceptive or } \\
\text { perverse }(\mathrm{A}, \mathrm{B}, \mathrm{C}, \mathrm{D}, \mathrm{E}, \mathrm{F}) \\
\text { Careful EC regulations will } \\
\text { reduce unforeseen negative } \\
\text { effects }(\mathrm{A}, \mathrm{E})\end{array}$ & $\begin{array}{l}\text { Various indirect } \\
\text { effects and } \\
\text { potential "ripple" } \\
\text { consequences to } \\
\text { policy } \\
\text { implementation. }\end{array}$ & $\begin{array}{l}\text { Build up a theoretical } \\
\text { framework that involves a } \\
\text { systematic approach to } \\
\text { tackle the potential } \\
\text { unintended consequences. }\end{array}$ & $\begin{array}{l}\text { Identify the various sources of } \\
\text { unintended consequences } \\
\text { (e.g. predict the potential } \\
\text { firms' responses to specific } \\
\text { measures before } \\
\text { implementation) }\end{array}$ \\
\hline $\begin{array}{l}\text { Dysfunctional effects of } \\
\text { performance measurement } \\
\text { - A robust measure is needed } \\
\text { for everyone to gear toward } \\
\text { the goal together with clear } \\
\text { objective (A, B, C, D, F) } \\
\text { A collaborative } \\
\text { relationship between policy } \\
\text { makers and firms (based on } \\
\text { mutual trust) is required for } \\
\text { long-term progress (A, C, } \\
\text { E) }\end{array}$ & $\begin{array}{l}\text { Various } \\
\text { categories of } \\
\text { dysfunctional } \\
\text { consequences of } \\
\text { performance } \\
\text { measurement } \\
\text { have been } \\
\text { identified. }\end{array}$ & $\begin{array}{l}\text { Expand the theoretical } \\
\text { framework by integrating } \\
\text { the various categories of } \\
\text { dysfunctional } \\
\text { consequences of } \\
\text { performance measurement } \\
\text { and their related remedies } \\
\text { for environmental } \\
\text { management. }\end{array}$ & $\begin{array}{l}\text {-Clearly defined, specific, } \\
\text { robust performance measures } \\
\text { should be adopted; } \\
\text {-Create accountability for } \\
\text { performance rather than only } \\
\text { rely on fear or punishment. }\end{array}$ \\
\hline
\end{tabular}

Note: $A, B, C, D, E, F$ refers to the case companies. 
Based on a systematic study of a sample of six firms and supporting examples from literatures and archival sources, this study has successfully examined the concept of unintended effects of environmental regulation and measures on firms' operations and related performance outcomes. Though only limited cases, but this research provides important insights and external validity of the empirical data, thus enable the findings to be generalizable to firms to a wider context such as in other emerging economies. This study also notices that the Chinese cultural value of "face" and reputation could play a vital role in addressing the unintended consequences of EC regulations. In the case study, it was highlighted by managers that large firms good reputation will lose face if EC targets were not met. The dominant Chinese cultural values are documented as high power distance, high uncertainty avoidance and low individualism (Hofstede, 1980). Respect for hierarchy or high power distance is still deep rooted among the majority of the Chinese people and greatly influences Chinese business culture ( $\mathrm{Li}$ and Tang, 2009). Future research could take into account of the Chinese cultural values. Moreover, based on six cases, the reported weaknesses, and unintended consequences of environmental regulation is limited and not comprehensive. Further research (more longitudinal and in-depth case studies) can provide further evidence to support the three themes identified in this study. In addition, a focus of heavy regulated industry sector (such as mining, power and utility) could provide better insights to strengthen the three identified themes.

\section{Acknowledgement}

The initial versions of this paper were presented at the APIEMS 2013, and ICPR 2015 conferences. The authors would like to thank the Tsinghua/ Nottingham Teaching and Research Fund for support of this research. The authors would also like to thanks various conference participants for their invaluable inputs.

\section{References}

Adcroft, A., Willis, R., 2005. The (un)intended outcome of public sector performance measurement. International Journal of Public Sector Management, 18 (5), 386-400. 
Bazerman, M.H. and Tenbrunsel, A.E. 2011. Ethical breakdowns. Harvard Business Review, 89(4), 58-65.

Blossom, .P. and Bradley, J.R. 1999. Mistakes Commonly Made Using Performance Measures to Motivate Employees, Cornell University.

Braithwaite, J. 1989. Crime, Shame and Reintegration. Cambridge: Cambridge Univeristy Press.

Bricknell, S. 2010. Environmental crime in Australia. Research and public policy series no. 109. Canberra: Australian Institute of Criminology. ISBN 9781921532641.

Brigham, B. and Fitzgerald, L. 2001, Controlling managers and organisations: The case of performance measurement in a regulated water company, Centre for Management under Regulation Research Paper 01/01, University of Warwick.

Brizga, J., Mishchuk, Z., and Golubovska-Onisimova, A. 2014. Sustainable consumption and production governance in countries in transition. Journal of Cleaner Production, .63, 4553.

Done, A., Voss, C., \& Rytter, N.G. 2011. Best practice interventions: Short-term impact and long-term outcomes. Journal of Operations Management, 29, 5, 500-513.

Eisenhardt, K. M. 1989. Building theories from case study research. Academy of Management Review, 14, 532-550.

Ellickson, R.C. 1987. A Critique to Economic and Sociological Theories of Social Control. Journal of Legal Studies, 16 (January), 67-99.

Feinstein, N. 2013. Learning from Past Mistakes: Future Regulation to Prevent Greenwashing, Boston College Environemtnal Affairs Law Review. 40 (1). http://lawdigitalcommons.bc.edu/ealr/vol40/iss1/6.

Foo, K. Y. 2013. A vision on the role of environmental higher education contributing to the sustainable development in Malaysia. Journal of Cleaner Production, 61, 6-12.

Gibbs, J.P. 1989. Control: Sociology's Central Notion. Beverly Hills. CA: Sage Publications.

Gilliland, D.I. and Manning, K.C. 2002. When do firms conform to regulatory control? The effect of control processes on compliance and opportunism. Journal of Public Policy \& Marketing, 319-331.

Goulder, L.H., Jacobsen, M.R, and Van-Benthem, A.A. 2012. Unintended Consequences from Nested State and Federal Regulations: The Case of the Pavley Greenhouse-Gas-Per-Mile Limits, Journal of Environmental Economics and Management, 63,187-207.

Huang, R. \& Chen, D. 2015. Does Environmental Information Disclosure Benefit Waste Discharge Reduction? Evidence from China. Journal of Business Ethics, 129, 3, p535552.

Hart, C. 1999. The Mysterious Placebo Effect. Modern Drug Discovery July/August.

Hilton, I. 2014. The environment. Australian Center on China in the world. http://www.thechinastory.org/lexicon/the-environment/ (accessed on 15 April 2015).

Hofstede, G. 1980. Culture's Consequences. Sage Publications, Berverly Hills, CA.

Humphreys, I., Francis, G., 2002. Performance measurement: a review of airports. International Journal of Transport Management 1, 79-85.

IPE (2015). Green Choice Alliance. www.ipe.org.cn. Accessed on 10 June 2015. 
Kaiman, J, 2013. Chinese environment official challenged to swim in polluted river. The Guardian, February 21, 2013 (accessed on 15 April 2015). http://www.theguardian.com/environment/2013/feb/21/chinese-official-swim-pollutedriver.

Li, P, and Tang, G. 2009. Performance measurement design within its organisational contextEvidence from China. Management Accounting Research. 20, 193-207.

Locke, K. 2001. Grounded theory in management research. London: Sage.

Lu, L.Y.Y., Wu, C.H., Kuo, T.-C. 2007. Environmental principles applicable to green supplier evaluation by using multi-objective decision analysis. International Journal of Production Research, 45, 18/19, p4317-4331.

Mathiesen, L. 2014. Why Licence Plate Bans Don't Cut Smog The Guardian. http://www.theguardian.com/cities/2014/mar/20/licence-plate-driving-bans-parisineffective-air-pollution. Accessed on 30 March 2015.

Merton, R. K. 1936. The Unanticipated Consequences of Purposive Social Action. American

Sociological Review 1 (6): 895.

Meyer, M. W. 2009. Rethinking Performance Measurement: Beyond the Balanced Scorecard. Cambridge University Press.

Miles, H. and Huberman, M. 1994, Qualitative Data Analysis: A Sourcebook, Sage Publications, Beverly Hills, CA.

Osborn, R.N. and Daniel H.J. 1988. Leaders, riverboat gamblers, or purposeful unintended consequences in the management of complex, dangerous technologies. Academy of Management Journal 31(4), 924-947.

Pagell, M. \& Wu, Z. 2009. Building a more complete theory of sustainable supply chain management using case studies of 10 exemplars. Journal of Supply Chain Management, $45,2,37-56$.

Powell, A.A. 2011. Unintended Consequences of Implementing a National Performance Measurement System into Local Practice. J Gen Intern Med, 27(4): 405-412.

Ridgway, V. F. 1956. Dysfunctional consequences of performance measurements. Administrative Science Quarterly 1(2): 240-247.

Roethlisberger, F.J. and Dickson, W.J. 1939. Management and the Worker. Cambridge, Mass., Harvard University Press.

Rosenthal, R. and Jacobson, L. 1968. Pygmalion in the classroom. New York: Holt, Rinehart \& Winston.

Saretsky, G. 1972. The OEO P.C. experiment and the. John Henry Effect, Phi Delta Kappan 53, $579-581$.

Scholz, John T. 1984. Voluntary compliance and regulatory enforcement. Law \& Policy, 6(4), 385-404.

Selznick, P. 1948. Foundations of the Theory of Organization." American sociological review, 25-35.

Shaffer, B. 1995. Firm-level responses to government regulation: theoretical and research approaches. Journal of Management, 21 (3), 495-514. 
Si, M. 2012. An insight into the green vocabulary of the Chinese communist party. Chinadiaglogue. https://www.chinadialogue.net/article/show/single/en/5339-An-insightinto-the-green-vocabulary-of-the-Chinese-communist-party (accessed on 27 August 2014).

Solomon, R.L. 1964. Punishment. American Psychologist. 19, 239-253.

Tan, K. and Rae, R. 2009. Uncovering the links between regulation and performance measurement, International Journal of Production Economics, 122, 449-457.

Tan, K., Shi, L., Tseng, M. and Chiu, A. 2014). Managing the Indirect Effects of Environmental Regulation and Performance Measurement, Industrial Engineering and Management Systems, 13 (2), 148-153.

Thorndike, E. L. 1920. A constant error in psychological ratings" Journal of Applied Psychology, 4(1), 25-29.

Tseng, M. Tan, K. Lim, M. Lin, R. and Geng, Y. 2014. Benchmarking eco-efficiency in Green Supply Chain Practices in Uncertainty, Production Planning and Control, 25(13-14), 1079-1090.

Waggoner, D., Neely, A. and Kennerley, M. 1999 The forces that shape organisational performance measurement systems: an interdisciplinary review, International Journal of Production Economics, 60/61 (3), 53-60.

Wang, Y., Liu, J., Hansson, L., Zhang, K., Wang, R. 2011. Implementing stricter environmental regulation to enhance eco-efficiency and sustainability: a case study of Shandong Province's pulp and paper industry, China, Journal of Cleaner Production, 19, 4, p303310.

Weidinger, C. and Platts, K. 2012. Evaluating the Effectiveness of Performance Measurement Systems. Seventeenth International Working Seminar on Production Economics. Innsbruck, Austria.

Wu, J., Lv, L.,Sun, J., \& Ji, X.2015. A comprehensive analysis of China's regional energy saving and emission reduction efficiency: From production and treatment perspectives, Energy Policy, 84, p166-176.

Yin, R. K. 1984. Case study research: Design and methods. Newbury Park, CA: Sage. 